\title{
KINERJA PROGRAM PENYALURAN BANTUAN LANGSUNG MASYARAKAT (BLM) PENGEMBANGAN USAHA MINA PEDESAAN (PUMP) PERIKANAN BUDIDAYA
}

\section{Performance Analysis of Distribution Program Live Aid Society (BLM) Small Aquaculture Business Program (PUMP)}

\author{
*Hikmah dan Maulana Firdaus \\ Balai Besar Riset Sosial Ekonomi Kelautan dan Perikanan \\ Gedung Balitbang KP I Lt. 4 \\ Jalan Pasir Putih Nomor 1 Ancol Timur, Jakarta Utara, Indonesia \\ Telp: (021) 64711583 Fax: 64700924 \\ Diterima tanggal:14 Pebruari 2017 Diterima setelah perbaikan: 19 April 2017 \\ Disetujui terbit: 6 Juni 2017 \\ *email: hikmah_madani@yahoo.com
}

\begin{abstract}
ABSTRAK
Program Nasional Pemberdayaan Masyarakat Mandiri Kelautan dan Perikanan merupakan integrasi dari kegiatan pemberdayaan Program PNPM Mandiri. Penelitian ini bertujuan untuk mengetahui dan mengevaluasi kinerja program penyaluran bantuan langsung tunai kepada masyarakat melalui program Pengembangan Usaha Mina Pedesaan-Perikanan Budidaya (PUMP-PB) dengan fasilitasi bantuan pengembangan usaha bagi pembudidaya ikan dalam wadah Kelompok Pembudidaya Ikan (POKDAKAN). Metode penelitian menggunakan metode survei pada 12 lokasi penelitian. Metode analisis data menggunakan analisis deskriptif kualitatif. Hasil penelitian menunjukkan bahwa capaian kinerja input, proses dan output pelaksanaan program penyaluran bantuan langsung masyarakat melalui PUMP-Perikanan Budidaya di 12 Kabupaten/Kota secara administrasi telah sesuai dengan petunjuk teknis dari Direktorat Jenderal Perikanan Budidaya. Hal ini ditunjukkan oleh jawaban responden terhadap empat isian terkait kegiatan tersebut yaitu $100 \%$ responden menyatakan sudah sesuai dengan prosedur. Dalam pelaksanaannya, masih terdapat permasalahan dan tantangan yang dihadapi antara lain adanya kelompok aspirasi, kurangnya tenaga pendamping, pencairan BLM tidak tepat waktu dan penerima BLM kurang tepat sasaran.
\end{abstract}

Kata Kunci: kinerja, bantuan langsung masyarakat, program PUMP perikanan budidaya

\section{ABSTRACT}

The National Program for Community Empowerment of Independent Marine and Fisheries is the integration of PNPM Mandiri Program empowerment activities. This study aimed to identify and evaluate the performance of direct cash transfer programs to the community through the small aquaculture business program (PUMP-PB) with the facilitation of business development assistance for fish farmers in the container Fish Farmers Group (Pokdakan). The research method used survey methods at 12 study sites. Methods of data analysis using qualitative descriptive analysis. The results showed that the gains of the input, process and output of the implementation of the distribution of community grants program through PUMP-Aquaculture in 12 districts/ cities in administration in accordance with the technical guidance of the Directorate General of Aquaculture. This is indicated by the respondents to the four fields related to these activities is $100 \%$ of the respondents are in accordance with the procedure. In practice, there are still problems and challenges faced by, among others, the existence of groups of aspiration, lack of assistants, not timely disbursement of BLM and less targeted recipients.

Keywords: performance, BLM, small aquaculture business program (PUMP) 


\section{PENDAHULUAN}

Beberapa hasil studi tentang masyarakat nelayan memberikan gambaran bahwa masyarakat nelayan identik dengan kemiskinan dan keterbelakangan, di tengah besarnya potensi perikanan yang dimiliki wilayah pesisir, yang seharusnya dapat dikelola untuk menyejahterakan masyarakat pesisir. Permasalahan kemiskinan yang terjadi di wilayah pesisir disebabkan oleh faktorfaktor kompleks yang saling terkait, di antaranya para nelayan bukan saja harus berhadapan dengan ketidakpastian pendapatan dan tekanan musim paceklik ikan, tetapi mereka juga dihadapkan pada permasalahan sistem dan struktur ekonomi mengikat yang membuat mereka terbelenggu dalam kemiskinan (Mala, 2016). Lebih lanjut Murdini et al. (2013)mengemukakan bahwaketerbatasan sumber daya manusia yang handal untuk mengelola potensi lokal, keterbatasan permodalan, keterbatasan akses terhadap informasi teknologi dan pasar, peluang usaha serta tantangan iklim. Oleh karena itu dipandang perlu adanya suatu program yang langsung menyentuh kepentingan masyarakat pesisir dan berorientasi pada pertumbuhan ekonomi dan dapat mendorong masyarakat untuk mengembangkan usahanya sesuai dengan potensi sumber daya yang tersedia dan dikelola secara partisipatif melibatkan masyarakat sebagai stakeholder utama. sebagai langkah nyata untuk mewujudkan peningkatan kesejahteraan tersebut pada tahun 2009 Kementerian Kelautan dan Perikanan telah meluncurkan Program Nasional Pemberdayaan Masyarakat Mandiri Kelautan dan Perikanan (PNPM-MKP) yang merupakan integrasi dari kegiatan pemberdayaan Program PNPM Mandiri (Utomo, 2011).

PNPM-MKP berupaya melaksanakan pendekatan dengan model bottom-up, yaitu masyarakat sendiri yang merencanakan program, melaksanakan dan melakukan monitoring dan evaluasisesuai dengan mekanismeyang ditentukan. Pengembangan program ini diberikan kepada masyarakat yang dibiayai dari Anggaran Tugas Pembantuan (TP), yaitu langsung dilaksanakan oleh Dinas Kabupaten/ Kota, yang dalam pelaksanaannya dibantu oleh konsultan pelaksana dan tenaga pendamping yang bertugas seharihari mendampingi pembudidaya dalam proses pemberdayaan. PNPM-MKP merupakan bagian dari proses pemberdayaan nasional yang dimaksudkan untuk menjadikan masyarakat sejahtera dan mandiri, serta mengurangi ketergantungan pada bantuan bantuan pemerintah yang diarahkan untuk memanfaatkan secara optimal kelembagaan masyarakat yang terbentuk sebelumnya. Beberapa kelembagaan kelompok yang telah terbentuk antara lain: Kelompok Pembudidaya Ikan (Pokdakan), Kelompok Usaha Bersama (KUB) Nelayan, Lembaga Ekonomi Pengembangan Pesisir Mikro Mitra Mina (LEPP-M3), kelompok pengolah dan pemasar (Poklahsar), kelompok pengolahan hasil perikanan serta Kelompok Masyarakat Pemanfaat (KMP). Keberhasilan program akan sangat bergantung dukungan dan kontribusi pemerintah daerah dalam bentuk kebijakan, peraturan dan perencanaan serta pendanaan (Kementerian Kelautan dan Perikanan (KKP), 2009).

Pada perikanan budidaya, PNPM-MKP dilaksanakan melalui Pengembangan Usaha Mina Pedesaan-Perikanan Budidaya (PUMP-PB) dengan fasilitasi bantuan pengembangan usaha bagi pembudidaya ikan dalam wadah Kelompok Pembudidaya Ikan (Pokdakan). Tujuan PUMP-PB, yaitu mendorong peningkatan produksi, nilai tambah, meningkatkan pendapatan, menumbuhkan wirausaha, meningkatkan fungsi kelembagaan kelompok pembudidaya ikan yang kuat serta membangun jejaring atau mitra lembaga keuangan dalam akses permodalan usaha perikanan budidaya (Direktorat Jenderal Perikanan Budidaya (DJPB), 2011). Keberhasilan program yang telah dilaksanakan maupun yang akan dilaksanakan membutuhkan monitoring dan evaluasi (Monev). Pada saat ini monitoring dan evaluasi pelaksanaan program pengentasan kemiskinan pada kelompokkelompok diukur secara non kuantitatif (baik, sedang dan kurang) dan secara kuantitatif. Pengukuran kuantitatif yaitu pengukuran yang dapat menunjukkan berapa persen pendapatan penduduk meningkat, dan berapa persen jumlah nelayan/ petani ikan miskin yang menjadi tidak miskin lagi per kabupaten dan per provinsi. Berdasarkan hal tersebut, maka diperlukan pengukuran kinerja program pengentasan kemiskinan yang lebih terukur sehingga dapat memecahkan permasalahan yang ada dan meningkat kesejahteraan masyarakat khususnya masyarakat kelautan dan perikanan. Penelitian ini bertujuan untuk menganalisis kinerja program penyaluran bantuan langsung masyarakat (BLM) pengembangan usaha mina pedesaan (PUMP), khususnya program yang terkait perikanan budidaya. 


\section{METODOLOGI}

\section{Waktu dan Tempat}

Penelitian ini dilaksanakan pada bulan April sampai dengan November 2014 di 12 lokasi kabupaten/ kota yaitu Banda Aceh, Sibolga, Pesisir Selatan, Tangerang, Sukabumi, Cirebon, Pamekasan, Banjar, Bitung, Lombok Timur, Kupang, dan Sorong. Penentuan lokasi dilakukan secara sengaja (purposive) dengan pertimbangan keterwakilan wilayah Indonesia bagian barat, timur dan tengah.

\section{Metode Penelitian}

Penelitian ini menggunakan pendekatan kuantitatif dengan metode penelitian survei, yaitu penelitian dengan mengambil sampel dari suatu populasi dan menggunakan kuesioner sebagai alat pengumpul data yang utama. Metode penelitian survei yaitu melakukan penelitian untuk memperoleh fakta-fakta dari gejala yang ada dan menjadi keterangan-keterangan secara faktual, baik secara institusi sosial, ekonomi dan politik dari suatu kelompok ataupun daerah (Nazir, 1999). Jenis data yang diperlukan dalam penelitian ini terdiri dua jenis, yaitu data primer dan data sekunder. Data primer diperoleh dari wawancara langsung dengan responden yaitu pembudidaya ikan yang berpedoman pada kuesioner yang telah disediakan. Sementara data sekunder dikumpulkan dengan teknik studi dokumentasi yang diperoleh dari instansi-instansi terkait (Idrus, 2009).

Tabel 1. Jumlah Populasi Berdasarkan Kelompok Penerima Dana PNPM Mandiri KP.

Table 1. Number of Population by Group of Beneficiaries of PNPM Mandiri KP.

\begin{tabular}{ccr}
\hline No & $\begin{array}{c}\text { Kabupaten/Kotal } \\
\text { Regency }\end{array}$ & $\begin{array}{c}\text { Populasi / } \\
\text { Population }\end{array}$ \\
\hline 1 & Banda Aceh & 110 \\
2 & Sibolga & 30 \\
3 & Pesisir Selatan & 90 \\
4 & Tangerang & 120 \\
5 & Sukabumi & 210 \\
6 & Cirebon & 280 \\
7 & Pamekasan & 60 \\
8 & Banjar & 320 \\
9 & Bitung & 80 \\
10 & Lombok Timur & 90 \\
11 & Kupang & 50 \\
12 & Kota Sorong & 100 \\
Total Sampel/Total Sample & $\mathbf{1 , 5 4 0}$ \\
\hline
\end{tabular}

\section{Pengambilan Sampel}

Populasi dalam penelitian ini adalah masyarakat pembudidaya. Teknik pengambilan sampel menggunakan pendekatan multi stage random sampling. Tahap pertama, pengambilan sampel populasi penelitian ditetapkan secara sengaja (purposive sampling), dimana populasi sampel merupakan keseluruhan dari jumlah masyarakat yang menerima bantuan PUMP perikanan budidaya dan mewakili wilayah bagian timur, barat dan tengah.

Tahap kedua, pengambilan sampel responden ditetapkan secara acak sederhana (simple random samping) sebanyak 10 persen dari jumlah populasi. Sebaran sampel responden penerima BLM PUMP-PB dapat dilihat pada Tabel 2 berikut.

Tabel 2. Jumlah Sampel Responden Berdasarkan Kelompok Penerima Dana PNPM Mandiri KP.

Table 2. Number of Sample Respondents Based on Beneficiaries Group of PNPM Mandiri KP.

\begin{tabular}{clr}
\hline No & $\begin{array}{c}\text { Kabupaten/Kota/ } \\
\text { CitylRegency }\end{array}$ & $\begin{array}{c}\text { Sampel/ } \\
\text { Sample }\end{array}$ \\
\hline 1 & Banda Aceh & 11 \\
2 & Sibolga & 3 \\
3 & Pesisir Selatan & 9 \\
4 & Tangerang & 12 \\
5 & Sukabumi & 30 \\
6 & Cirebon & 28 \\
7 & Pamekasan & 6 \\
8 & Banjar & 32 \\
9 & Bitung & 8 \\
10 & Lombok Timur & 9 \\
11 & Kupang & 5 \\
12 & Kota Sorong & 10 \\
Total Sampel / Total Sample & 163 \\
\hline
\end{tabular}

\section{Analisis Data}

Metoda analisis data dan informasi menggunakan analisis kualitatif berdasarkan penelaahan pada setiap pedoman teknis pelaksanaan PNPM Mandiri KP, indikator kinerja PNPM Mandiri KP dalam hal ini pedoman teknis PUMP Perikanan Budidaya. Analisis kualitatif yaitu segala sesuatu yang diperoleh dari yang dilihat, didengar dan diamati. Dengan demikian, data dapat berupa catatan lapangan sebagai hasil 
amatan, deskripsi wawancara, catatan harian, foto, pengalaman pribadi, jurnal, cerita sejarah dan banyak hal lain sebagai hasil pengamatan dan pendengaran (Idrus, 2009).

Analisis kinerja program PNPM Mandiri tersebut mencakup indikator input, proses dan output. Kinerja input adalah kegiatan dan sumber daya/ dana yang dibutuhkan agar keluaran sesuai dengan apa yang diharapkan. Kinerja proses adalah kegiatan pengelolaan input sampai menghasilkan output. Dan kinerja output adalah sesuatu yang langsung diperoleh/ dicapai dari pelaksanaan kegiatan. Pada analisis ini dilihat skor seberapa besar persentase tingkat ketepatan atas kinerja program PNPM Mandiri. Analisis kuantitatif untuk menentukan skor atas ketepatan dilakukan melalui analisis statistik dengan menggunakan skala likert (sebagai salah satu skala sikap). Skala ini terdiri atas sejumlah pernyataan yang semuanya menunjukkan sikap terhadap suatu obyek tertentu atau menunjukkan ciri tertentu yang akan diukur (Soehartono, 2008). Untuk pengembangan teknik analisis penelitian yang akan mengarah pada pengukuran sikap, terutama untuk keperluan konfirmasi (cross check) pernyataan informan. Jawaban dari setiap item variabel dari skala likert mempunyai gradasi (jenjang atau tingkat), dari sangat positif sampai sangat negatif yang dapat berupa kata.

\section{HASIL DAN PEMBAHASAN}

\section{Kinerja Input dalam Pelaksanaan PUMP-PB}

Kinerja input merupakan tahapan yang harus dilakukan untuk pengusulan bantuan dalam PNPM Mandiri KP. Tahapan dalam kinerja input meliputi tahap identifikasi, seleksi, verifikasi, dan penetapan calon Pokdakan penerima bantuan, penyiapan dokumen dan verifikasi dokumen. Secara administrasi, kinerja input pada tahap identifikasi, seleksi, verifikasi dan penetapan calon Pokdakan penerima bantuan PUMP-Perikanan Budidaya di 12 Kabupaten/Kota telah sesuai dengan petunjuk teknis dari Direktorat Jenderal Perikanan Budidaya. Hal ini ditunjukkan oleh jawaban responden terhadap empat isian terkait kegiatan tersebut yaitu $100 \%$ responden menyatakan sudah sesuai dengan prosedur. Sejalan dengan hasil berdasarkan wawancara secara mendalam kepada informan kunci, kesesuaian dalam pelaksanaannya terjadi variasi jawaban responden pada ketiga lokasi panelitian.
Sebagai contoh untuk lokasi Sukabumi dalam proses verifikasi, nama-nama Pokdakan ada yang belum terdaftar di Dinas Kelautan dan Perikanan dimana kelompok-kelompok tersebut merupakan kelompok aspirasi namun lulus seleksi. Hal ini menimbulkan dilema bagi petugas pendamping (PPTK) dan Dinas Kelautan dan Perikanan setempat. Hal ini juga terjadi di Lombok timur. Secara administrasi proses verifikasi untuk lokasi Lombok Timur untuk pemenuhan kriteria umum dan khusus calon penerima program yang sesuai dengan ditetapkan Direktorat Jenderal Teknis (Ditjen Teknis) menurut jawaban responden 25\% menjawab 'sedang' dan 75\% menjawab 'baik' dan pertanyaan ketiga $100 \%$ responden menjawab 'baik'. Namun tentang kesesuaian tahapan pengusulan dan penetapan penerima program belum sesuai dengan prosedur yang ditetapkan oleh Ditjen Teknis responden menjawab 50\% 'sedang' dan 50\% 'baik'. Beberapa yang ditemui di lapang terkait dengan hal tersebut adalah waktu yang diperlukan dalam pengusulan dan penetapan penerima program hanya berlaku singkat. Pokdakan tidak mengetahui secara jelas tahapan dalam pengusulan penerimaan program. Ketua kelompok yang telah dipilih menghandle seluruh tahapan mulai dari menyiapkan berkas sampai dengan memperbaiki berkas apabila perlu diperbaiki. Umumnya Pokdakan menerima beres pengusulan bantuan ini dan berusaha melaksanakan apa yang diminta oleh tim teknis dan tenaga pendamping.

Begitu pula di Kabupaten Pesisir Selatan, pada tahapan ini semua persyaratan telah dilakukan sesuai dengan petunjuk teknis, namun adanya perbedaan tingkat kesesuaianya. Walaupun semua syarat telah dipenuhi namun tingkat kesesuaiannya secara umum dapat dikatakan sedang. Hal ini disebabkan oleh keterbatasan informasi dan pengetahuan dari calon penerima program terhadap persyaratan-persyaratan sebagai penerima program.

Penyiapan dokumen dilakukan dalam bentuk penyusunan proposal, RUK (Rencana Usaha Kelompok) dan RUB (Rencana Usaha Bersama). Penyiapan dokumen pada lokasi Kabupaten Sukabumi dilakukan oleh kelompok yang difasilitasi tokoh masyarakat setempat bukan oleh tenaga pendamping. Hal ini disebabkan pada tahun 2012 di Kabupaten Sukabumi belum ada tenaga pendamping (PPTK) untuk PUMP perikanan budi daya sehingga dokumen yang telah disusun sudah sesuai dengan pedoman teknis. 
Tabel 3. Kinerja Input dalam Pelaksanaan PUMP-PB di Lokasi Penelitian, 2014. Table 3. Input Performance in PUMP-PB Implementation at Research Sites, 2014.

\begin{tabular}{|c|c|c|}
\hline $\begin{array}{l}\text { Input/ } \\
\text { Input }\end{array}$ & $\begin{array}{l}\text { Pelaksanaan I } \\
\text { Implementation }\end{array}$ & $\begin{array}{l}\text { Permasalahan/ } \\
\text { Issues }\end{array}$ \\
\hline \multirow{3}{*}{$\begin{array}{l}\text { Identifikasi, seleksi, } \\
\text { verifikasi, penetapan } \\
\text { calon KUB penerima } \\
\text { bantuan, penyiapan } \\
\text { dokumen dan verifikasi } \\
\text { dokumen/ Identification, } \\
\text { selection, verification, } \\
\text { determination of candidate } \\
\text { KUB candidates, document } \\
\text { preparation and document } \\
\text { verification }\end{array}$} & \multirow{3}{*}{$\begin{array}{l}100 \% \text { terlaksana sesuai } \\
\text { dengan pedoman } \\
\text { teknis PUMP PB/ } \\
100 \% \text { implemented in } \\
\text { accordance with PUMP } \\
\text { PB technical guidelines }\end{array}$} & $\begin{array}{l}\text { KUB tidak mengetahui secara jelas tahapan } \\
\text { dalam pengusulan penerimaan program/ } \\
\text { KUB does not know clearly the stages in the } \\
\text { proposed acceptance of the program }\end{array}$ \\
\hline & & $\begin{array}{l}\text { - Keterbatasan informasi dan pengetahuan } \\
\text { dari calon penerima program terhadap } \\
\text { persyaratan-persyaratan sebagai penerima } \\
\text { program/ Limitations of information and } \\
\text { knowledge of potential recipients of the } \\
\text { program on the requirements of the } \\
\text { program beneficiaries }\end{array}$ \\
\hline & & $\begin{array}{l}\text { - Adanya kelompok aspirasi menghambat } \\
\text { proses verifikasi/ The presence of } \\
\text { aspiration groups hampers the verification } \\
\text { process }\end{array}$ \\
\hline
\end{tabular}

Sumber: Data primer diolah, 2014/Source: Primary Data Processed, 2014

Hal ini berbeda dengan kondisi yang ada di Kabupaten Lombok Timur. Berdasarkan wawancara dengan responden, seluruh tahapan penyiapan dokumen sudah sesuai dengan tahapan pada pedoman teknis dan pelaksanaannya tergolong baik. Pada proses pemilihan Pokdakan calon penerima di Kabupaten Lombok Timur terdapat ketidaksesuaian dengan pedoman teknis, contohnya penyiapan dokumen tidak dilakukan oleh seluruh anggota Pokdakan (tiba-tiba sudah jadi dan lengkap), waktu pengusulan dokumen sampai dengan penerimaan dana terlalu singkat, dan dokumen yang diterima oleh tim teknis tidak diberikan kepada KUB penerima program sebagai berkas yang wajib disimpan. Permasalahan ketidaksesuaian pemilihan Pokdakan calon penerima bantuan hampir terjadi di seluruh lokasi penelitian seperti Kabupaten Sukabumi, Lombok Timur dan Kabupaten Pesisir Selatan, sedangkan untuk di Kota Kupang penyiapan dokumen dilakukan kelompok yang difasilitasi oleh tokoh masyarakat setempat dan tenaga pendamping. Tokoh masyarakat tersebut merupakan pelopor kegiatan budi daya ikan air tawar di Kota Kupang. Masyarakat Kota Kupang lebih memilih ikan laut daripada ikan air tawar untuk dikonsumsi, hal ini yang menyebabkan usaha budi daya ikan air tawar di Kota Kupang tidak berkembang.

\section{Kinerja Proses dalam Pelaksanaan PUMP-PB}

Kinerja proses merupakan tahapan yang terkait dengan proses turunnya bantuan terkait
PNPM Mandiri KP dari pemerintah kepada masyarakat atau kelompok penerima. Tahapan yang harus dilalui antara lain adalah sosialisasi, pelatihan, pendampingan, prosedur penyaluran, penarikan dan pemanfaatan dana BLM PUMP-PB, pembinaan dan pengendalian, evaluasi dan pelaporan. Pada tahap sosialisasi, pelatihan dan pendampingan terlihat bahwa $100 \%$ responden pada 12 lokasi penelitian menyatakan sudah sesuai dengan prosedur dengan pelaksanaan yang baik. Demikian pula kegiatan sosialisasi pedoman umum, pedoman teknis telah disosialisasikan bagaimana tata cara (prosedur) untuk mendapat BLM (PUMP-PB) sampai kepada pelaporan, monitoring dan evaluasinya kepada stakeholder yang terkait antara lain Dinas Kelautan dan Perikanan Kabupaten Sukabumi, Penyuluh Perikanan, PPTK, serta perwakilan kelompok-kelompok pembudi daya melalui presentasi dan workshop. Beberapa syarat untuk rekruitmen tenaga pendamping sudah sesuai dengan persyaratan, kecuali untuk tempat tinggal di lokasi sasaran yang jauh dari jangkauan tenaga pendamping.

Peran pendamping sesuai dengan pedoman teknis antara lain melakukan identifikasi dan seleksi calon lokasi dan Pokdakan calon penerima BLM PUMP-PB di kabupaten/ kota, melakukan identifikasi kelayakan kegiatan usaha Pokdakan calon penerima BLM PUMP-PB, memberikan bimbingan teknis dan manajemen usaha perikanan budi daya, membantu dan mendampingi Pokdakan dalam penyusunan RUK, RUB dan dokumen 
administrasi untuk pencairan dana BLM PUMP-PB, membantu memfasilitasi kemudahan akses terhadap pengadaan sarana produksi, teknologi dan pasar, membantu memecahkan permasalahan yang dihadapi oleh Pokdakan, membantu Pokdakan membuat laporan pemanfaatan PUMP-PB dan hasil pelaksanaan kegiatan pendampingan yang dikumpulkan ke Direktorat Jenderal Budidaya setiap tahun.

Kegiatan sosialisasi dalam bentuk pertemuan dengan pemangku kepentingan yang dilakukan di Dinas Kelautan dan Perikanan pada lokasi penerima telah dilakukan oleh Direktorat Jenderal Perikanan Budi daya. Namun pembekalan terhadap tenaga pendamping dirasakan masih kurang. Tenaga pendamping hanya dibekali pedoman teknis secara teknis pelaksanaan kegiatan pendampingan telah dilaksanakan dengan baik oleh PPTK. Sementara Djalal dan Lasabuda (2012) mengemukakan pengawasan dan pendampingan harus lebih intens terhadap kelompok masyarakat penerima bantuan program.

Prosedur penyaluran BLM kepada kelompok calon penerima sudah berjalan sesuai dengan pedoman teknis. Secara administrasi persyaratanpersyaratan yang telah ditetapkan oleh Direktorat Jenderal Perikanan Budi daya telah dilaksanakan dengan baik, mulai dari pembelian bahan dalam bentuk input produksi yaitu bibit/ benih, vitamin, pakan, dan saprokan dengan melampirkan bukti pembelian berupa kwitansi, faktur, nota atau bukti pembelian lainnya. Prosedur penarikan dana BLM Program PNPM Mandiri KP sesuai dengan pedoman teknis yaitu pengecekan rekening oleh Pokdakan setelah terbit Surat Perintah Pencairan Dana (SP2D) dan penarikan dana sesuai dengan kebutuhan Pokdakan dan kesepakatan tim teknis dan tim pendamping.

Sebagai contoh di Kabupaten Sukabumi responden menyatakan penarikan dana sudah sesuai dengan RUB, di Lombok Timur responden menyatakan bahwa tahap ini sudah sesuai dengan pedoman teknis namun dalam pelaksanaannya seringkali terlambat dalam pelaksanaannya. Hal ini menjadi keluhan Pokdakan karena ketika mereka membutuhkan input produksi, dana belum turun. Untuk pemanfaatan dana BLM program PUMP PB yang tidak sesuai atau terjadi perubahan dari RUB yang telah dibuat maka harus dibuat juga Berita Acara Perubahan RUB seperti tercantum pada pedoman teknis PUMP PB. Sementara di Kabupaten Pesisir Selatan, pada tahapan ini terdiri dari prosedur penyaluran dana BLM dari pemberi (Kementerian Kelautan dan Perikanan (KKP)) kepada kelompok penerima, proses penarikan dana dan pemanfaatan dana tersebut.

Tabel 4. Kesesuaian dan Pelaksanaan Kinerja Proses dalam Pelaksanaan PUMP-PB di Lokasi Penelitian, 2014.

Table 4. Conformity and Implementation of Process Performance in Implementation of PUMP-PB at Research Sites, 2014.

\begin{tabular}{|c|c|c|}
\hline Input/Input & $\begin{array}{l}\text { Pelaksanaan I } \\
\text { Implementation }\end{array}$ & Permasalahan/Issues \\
\hline $\begin{array}{l}\text { - Sosialisasi, pelatihan dan } \\
\text { pendampingan/ Socialization, } \\
\text { training and mentoring } \\
\text { - Prosedur penyaluran, } \\
\text { penarikan dan pemanfaatan } \\
\text { dana BLM PUMP-PB/ } \\
\text { Procedures for channeling, } \\
\text { withdrawing and utilizing BLM } \\
\text { PUMP-PB funds } \\
\text { - Pembinaan dan pengendalian, } \\
\text { dan bagaimana evaluasi } \\
\text { dan pelaporan sudah sesuai } \\
\text { dengan prosedur atau tidak } \\
\text { / Guidance and control, and } \\
\text { how evaluation and reporting } \\
\text { are in accordance with the } \\
\text { procedure or not }\end{array}$ & $\begin{array}{l}\text { - } 100 \% \text { terlaksana sesuai } \\
\text { dengan pedoman teknis } \\
\text { PUMP PB / 100\% is } \\
\text { executed in accordance } \\
\text { with PUMP PB technical } \\
\text { guidelines }\end{array}$ & $\begin{array}{l}\text { - Kurangnya tenaga pendamping } \\
\text { dalam melakukan pendampingan } \\
\text { dan bimbingan di lapangan/ Lack } \\
\text { of escort personnel in carrying out } \\
\text { mentoring and guidance in the field } \\
\text { - Keterbatasan pengetahuan dan } \\
\text { keterampilan/ Limitations of } \\
\text { knowledge and skills } \\
\text { - Insentif dan sarana prasarana } \\
\text { serta biaya operasional yang } \\
\text { kurang memadai termasuk } \\
\text { jangkauan wilayah yang terlalu } \\
\text { luas/ Insufficient infrastructure } \\
\text { and infrastructure incentives and } \\
\text { operational costs including a wide } \\
\text { range of areas }\end{array}$ \\
\hline
\end{tabular}

Sumber: Data primer diolah, 2014/Source: Primary Data Processed, 2014 
Secara keseluruhan berdasarkan hasil penelitian diketahui bahwa prosedur penyaluran dana dan proses penarikan sudah sesuai dengan pedoman teknis yang ada. Hal tersebut dapat dilihat sebanyak $100 \%$ responden yang menjawab sesuai, sedangkan untuk pemanfaatan dana BLM walaupun semuanya sesuai, namun pada tahapan pelaksanaannya tidak semuanya baik, sebagai contoh ada sebanyak $50 \%$ responden yang menjawab bahwa kelompok penerima tidak memanfaatkan dana yang ada sesuai dengan usulan. Seharusnya untuk dibelikan barang tertentu sesuai pada RUB namun ternyata barang tersebut tidak tersedia pada lokasi, sehingga diberikan jenis barang lainnya. Ada juga sebagian penerima yang memanfaatkan dana bantuan untuk memperbaiki rumah atau membeli barang elektronik di rumah seperti televisi dan kulkas. Hal ini menggambarkan bahwa kontrol dan pengawasan dari pemerintah terhadap program ini masih lemah. Sementara Karsidi (2001) mengungkapkan semua kegiatan yang kemudian dilaksanakan perlu dipantau secara berlanjut oleh penyuluh bersama sasaran penyuluhan untuk melihat kesesuaiannya dengan rencana yang telah disusun. Jika menyimpang, tentu perlu diusahakan tindakan-tindakan yang sesuai untuk mengarahkan kembali.

Tahap pembinaan dan pengendalian dilakukan secara berjenjang dari tingkat kabupaten/ kota, tingkat provinsi kemudian tingkat pusat. Kesesuaian dengan pedoman teknis sudah sesuai dan baik, begitu juga untuk pelaksanaannya. pembinaan tingkat pusat dilakukan dalam bentuk konsolidasi dan kunjungan lapang, pembinaan tingkat provinsi telah dilakukan dalam bentuk evaluasi dan pelaporan serta kunjungan lapang ke kabupaten/ kota berdasarkan lokasi yang telah ditentukan. Apabila terjadi permasalahan, maka pengendalian dilakukan oleh tim teknis dan tim pembina.

Pembinaan di tingkat kabupaten dilakukan dalam bentuk penyuluhan dan pendampingan (pertemuan bulanan) dengan Pokdakan. Di Kabupaten Pesisir Selatan pada tahapan ini terdiri dari pembinaan dan pengendalian yang dilakukan dari tingkat pusat (KKP), tingkat provinsi dan kabupaten terhadap para tenaga pendamping terkait tugas dan kewajibannya. Secara keseluruhan proses pembinaan dan pengendalian dari tingkat pusat, provinsi dan kabupaten telah dilakukan, namun untuk pembinaan dan pengendalian yang dilakukan oleh tim pusat belum sesuai atau tidak menyeluruh. Hal ini ditunjukkan oleh sebanyak $75 \%$ responden yang menjawab tidak sesuai. Dalam pelaksanaannya tidak semua proses pembinaan dan pengendalian baik dari tingkat pusat, provinsi dan kabupaten sesuai dengan pedoman yang ada. Contohnya pada frekuensi kunjungan pembinaan baik dari tingkat pusat dan provinsi yang tidak sesuai dengan rencana sebelumnya.

Proses pembinaan dan pengendalian merupakan salah satu cara untuk mengevaluasi terhadap kinerja para tenaga pendamping dan juga sebagai forum atau wadah pencarian solusi terhadap permasalahan yang dihadapi para tenaga pendamping. Semakin baik pelaksanaan tahapan ini maka diharapkan akan semakin baik pula kinerja dari para tenaga pendamping yang ada.

Tahap evaluasi dan pelaporan merupakan tahap akhir dalam kinerja proses. Evaluasi dilakukan oleh tim kelompok kerja (pokja) (tingkat pusat, tingkat provinsi dan tingkat kabupaten). Evaluasi dilaksanakan pada tahap awal pelaksanaan dan akhir untuk menilai kinerja pelaksanaan, manfaat dampak dan keberlanjutan kegiatan serta untuk mengetahui kelemahan dan permasalahan yang terjadi.

Berdasarkan hasil penelitian, tahapan evaluasi telah dilaksanakan sesuai dengan format isian yang ditetapkan dalam pedoman teknis dan pelaksanaannya tergolong baik. masing-masing kelompok usaha bersama yang telah mendapatkan BLM PUMP PB membuat laporan bulanan, semesteran dan akhir tahun. Di Kabupaten Lombok Timur, tahapan evaluasi yang dilakukan sudah sesuai dengan pedoman teknis dan pelaksanaannya tergolong baik. Sedangkan untuk tahap pelaporan dilakukan dalam bentuk laporan bulanan, semesteran, dan akhir tahun.

Laporan bulanan merupakan laporan yang disusun oleh Pokdakan yang berisi tentang produksi, nilai produksi, biaya produksi, pendapatan, tabungan, penambahan aset usaha, serta permasalahan dan solusi. Sedangkan laporan semesteran dan laporan tahunan disusun oleh pendamping, yang berisi tentang perkembangan realisasi kegiatan PUMP PB. Namun di Kabupaten Pesisir Selatan, seluruh proses evaluasi dan pelaporan untuk program PUMP perikanan budi daya belum semuanya telah dilakukan. Hal ini dikarenakan ada kelompok penerima yang baru menerima pada tahun 2014 dan ada juga yang baru menerima pada tahun 2013. Hal ini dapat dilihat 
dari banyaknya $75 \%$ responden yang menjawab sesuai dan $25 \%$ menjawab tidak sesuai.

Adapun permasalahan yang dihadapi pada tahapan pelaporan adalah ketepatan waktu dari pengumpulan laporan tersebut. Hal ini dapat dilihat dari besarnya tingkat pelaksanaan dalam kategori baik menurut jawaban responden sebanyak $75 \%$. Untuk evaluasi awal, pelaksanaan dan akhir yang dilakukan yaitu terhadap penerimaan program pada tahun sebelumnya (2012), menurut responden semua tahapan telah sesuai dilakukan namun untuk pelaksanaannya tidak seluruhnya pada kategori baik atau hanya sebanyak $50 \%$, hal ini dikarenakan oleh isi dari laporan yang kurang sesuai dengan petunjuk pada pedoman yang ada.

\section{Kinerja Output dalam Pelaksanaan PUMP-PB}

Kinerja output merupakan tolok ukur kinerja berdasarkan produk (barang dan jasa) yang dihasilkan dari program atau kegiatan sesuai dengan masukan yang digunakan. Menurut pendapat Hikmayani et al. (2013) keberhasilan Program PUMP PB ditentukan oleh dukungan kebijakan pemerintah daerah, status lahan dan ketepatan turunnya bantuan.

Di Kabupaten Sukabumi, kinerja output terhadap target jumlah penerima bantuan sudah tercapai $100 \%$. Dari sisi target penerima bantuan belum seluruhnya tepat sasaran. Hal ini disebabkan adanya kelompok-kelompok aspirasi yang mendapatkan bantuan sementara kelompok tersebut belum terdaftar di Dinas Kelautan dan Perikanan. Sementara kelompok yang sudah ada sejak lama berdiri dan terdaftar di Dinas Kelautan dan Perikanan ada yang tidak mendapatkan bantuan PUMP PB. Namun demikian, kelompok aspirasi penerima bantuan tersebut juga sudah melakukan kegiatan budi daya sejak lama namun tidak membentuk kelompok usaha bersama.

Ketepatan waktu penyaluran bantuan sudah sesuai dengan waktu dan musim tanam yang dilakukan oleh KUB. Kemudian sarana dan sarana yang diberikan sesuai dengan kebutuhan KUB. Dari sisi kelembagaan, kegiatan fasilitasi penguatan kapasitas dan kelembagaan berupa pelatihan dan pendampingan pada kelompok/ pihak penerima program sudah dilakukan pendamping maupun penyuluh dan difasilitasi oleh Dinas Kelautan dan Perikanan Kabupaten Sukabumi sudah sesuai namun dirasakan masih kurang. Sementara kelembagaan penyuluh dan tenaga pendamping masih kurang maksimal karena luasnya wilayah yang harus dikunjungi, sedangkan jumlah tenaga penyuluh dan tenaga pendamping masih minim. Disamping itu sarana dan prasarana penunjang kegiatan pendampingan pun masih minim. Padahal menurut Karsidi (2001), penyuluhan berperan meningkatkan kualitas sumber daya manusia (SDM), terutama dalam membentuk dan mengubah perilaku masyarakat untuk mencapai taraf hidup yang lebih berkualitas. Dalam hal keberlanjutan usaha KUB setelah menerima bantuan PUMP PB mengalami peningkatan usaha, baik dari sisi penambahan jumlah luas lahan, produksi dan pendapatan dan tabungan KUB pun meningkat.

Kabupaten Lombok Timur penerimaan BLM PNPM terkait dengan target jumlah program PNPM yang tercapai sudah sesuai dengan pedoman teknis PUMP PB dengan pelaksanaan yang tergolong baik. Penyaluran (jumlah bantuan) PNPM Mandiri KP sudah tepat sasaran dan tepat jumlah dengan pelaksanaan tergolong sedang. Sedangkan untuk penyaluran PNPM Mandiri, sebagian responden mengatakan bahwa belum sesuai dengan pedoman teknis yaitu belum sesuai dengan musim produksi, seringkali bantuan turun dengan waktu yang bergeser dari yang diperkirakan. Hal ini mengakibatkan pembelian input produksi terutama bibit atau benih terlambat dan mengakibatkan bergesernya waktu tanam. Jika pergeseran musim tanam bertepatan dengan musim panceklik hal ini akan berakibat fatal. Meskipun terkadang penyaluran BLM tersebut tidak sesuai namun pelaksanaannya tergolong baik. Untuk penyaluran PNPM terkait dengan pengadaan dan perbaikan sarana usaha perikanan sudah sesuai dengan yang dibutuhkan yaitu dalam bentuk sarana produksi ikan (peralatan pembuatan keramba, tali, karung, pelampung, serok, ember plastik, happa dan sebagainya). Kesesuaian pada tahap ini tergolong sedang sedangkan pelaksanaannya tergolong baik.

Kegiatan fasilitasi penguatan kapasitas dan kelembagaan berupa pelatihan dan pendampingan pada kelompok/ pihak penerima program sudah dilakukan pendamping maupun penyuluh dan difasilitasi oleh Dinas Kelautan dan Perikanan Kabupaten Lombok Timur dalam bentuk pelatihan teknologi budi daya rumput laut yaitu teknologi pembuatan longline sebagai pengganti teknologi budi daya menggunakan patok, cara pengikatan bibit rumput laut, kadar garam dan cara penjemuran yang baik. Selain pelatihan juga diadakan pendampingan oleh penyuluh di bawah koordinasi Badan Pelaksana Penyuluhan Pertanian, Perikanan 
dan Kehutanan (BP4K) dalam bentuk pertemuan rutin yang diadakan sebulan sekali, membahas permasalahan terkait budi daya dan solusi yang diharapkan. Sehingga untuk tahap ini menurut responden sudah sesuai dengan pelaksanaan tergolong baik.

Peran penyuluh dan pendamping juga diperlukan pada saat pembentukan kelembagaan KUKP (KUB) sebagai fasilitator. Salah satu syarat pengajuan bantuan PNPM Mandiri KP adalah KUB mempunyai struktur organisasi Ketua, Sekretaris, Bendahara, dan Anggota. Pembentukan KUB dibentuk secara langsung ketika ada informasi dari Dinas Kelautan dan Perikanan mengenai turunnya PNPM Mandiri KP tersebut. Pembentukan struktur organisasi KUB dilakukan bersama-sama oleh KUB secara musyawarah. Penunjukan ketua, sekretaris dan bendahara berdasarkan pengalaman usaha, keterampilan dan pengetahuan lebih tinggi dari yang lain serta mampu mengkoordinir teman yang lain.

Kinerja output pelaksanaan PNPM Mandiri $\mathrm{KP}$ dalam hal keberlanjutan usaha terkait dengan keberhasilan usaha penerima BLM PNPM Mandiri $\mathrm{KP}$ dengan indikator sebagai berikut (Tabel 5).

1. Kondisi usaha perikanan yang dilakukan setelah mendapatkan bantuan PNPM menjadi lebih baik. Berdasarkan wawancara dengan responden terlihat dalam laporan perkembangan usaha budi daya terjadi kenaikan produksi setelah mendapat BLM
PUMP-PB, terjadi kenaikan produksi ikan nila dari $9.135 \mathrm{~kg}$ (sebelum adanya PUMPPB) menjadi $11.940 \mathrm{~kg}$ (setelah turunnya PUMP-PB). Kenaikan produksi ini akan mempengaruhi kenaikan pendapatan usaha KUB sehingga dapat meningkatkan ekonomi keluarga dan meningkatkan skala usaha budi daya mereka. Kendala yang dihadapi oleh pembudi daya ikan nila pada tahun 2013 adalah harga pakan yang mahal. Hal ini menggambarkan adanya kesesuaian program PUMP PB. Pelaksanaan di lapang terlihat bahwa sebagian responden menjawab sedang, karena untuk KUB Gili Permai yang mendapat bantuan untuk budi daya ikan kerapu belum merasakan panen, karena sampai dengan tahun berikutnya (Januari 2014) masih dalam tahap pemeliharaan sehingga belum mengetahui keberhasilan pelaksanaan program PUMP PB ini.

2. Teknologi anjuran KKP dapat digunakan dan diaplikasikan

PUMP Perikanan Budi daya di Kabupaten Lombok Timur dari tahun 2011-2013 diberikan untuk budi daya dengan komoditas rumput laut, nila, dan kerapu. Teknologi yang diintroduksi ke KUB oleh KKP melalui Dinas Kelautan dan Perikanan adalah teknologi budi daya rumput laut dengan teknik longline. Sampai saat ini masyarakat menggunakan teknologi longline karena dirasakan

Tabel 5. Kesesuaian Pelaksanaan Kinerja Output dalam Pelaksanaan PUMP-PB di Lokasi Penelitian, 2014.

Table 5. Compliance Implementation of Output Performance in Implementation of PUMP-PB in Research Sites, 2014.

\begin{tabular}{lcl}
\hline \multicolumn{1}{c}{ Output / Output } & Pelaksanaan/ Implementation & \multicolumn{1}{c}{ Permasalahan/ Issues } \\
\hline $\begin{array}{l}\text { Target jumlah penerima } \\
\text { BLM/ Target number of BLM } \\
\text { recipients }\end{array}$ & $\begin{array}{l}\text { 100\% tercapai sesuai dengan } \\
\text { sasaran/ } 100 \% \text { achieved in } \\
\text { accordance with the objectives } \\
\text { BLM funds }\end{array}$ & $\begin{array}{l}\text { Waktu pencairan dana BLM } \\
\text { mengalami Keterlambatan/ } \\
\text { Disbursement time delays }\end{array}$ \\
Target sasaran penerima & $-50 \%$ tercapai sesuai dengan & Penerima BLM masih kurang tepat \\
program bantuan PUMP/ & sasaran/ 50\% achieved in & sasaran karena masih adanya \\
Target beneficiaries of the & accordance with the target & kelompok aspirasi/ BLM recipients \\
PUMP aid program & $-50 \%$ kurang sasaran/ $50 \%$ less & are still less targeted because \\
& target & there is still a group of aspirations \\
Tepat Waktu/ On Time & $-50 \%$ sudah tepat waktu/ $50 \%$ is & Kurang tepat waktu/ Less timely \\
& on time & \\
& on time Less timely & \\
& &
\end{tabular}

Sumber: Data primer diolah, 2014/Source: Primary Data Processed, 2014 
lebih menguntungkan dibandingkan dengan menggunakan teknologi patok. Keuntungan teknologi longline adalah bibit rumput laut tidak hanyut terbawa arus laut sehingga jumlah yang dipanen lebih banyak.

3. Bantuan program PNPM ini dimanfaatkan untuk pengembangan usaha dan tidak dimanfaatkan untuk non usaha (seperti konsumsi rumah tangga, sosial, dijual kembali dan lainnya)

Di Kabupaten Lombok Timur, seluruh bantuan PUMP-PB digunakan untukpengembangan usaha budi daya dan tidak dimanfaatkan untuk non usaha. Pemanfaatan untuk pengembangan usaha dalam hal pengadaaan input produksi (bibit, benih, pakan, vitamin, saprokan, dan perbaikan konstruksi lahan). Pelaksanaan yang dari tahap ini tergolong baik, sesuai dengan yang ada di lapang. Sementara target penerima program bantuan PUMP perikanan budi daya di Kabupaten Pesisir Selatan tidak mencapai target, yaitu sebanyak $50 \%$ responden yang menjawab tidak tercapai. Untuk ketepatan sasaran penerima program dinilai sudah tepat 100\%. Untuk keberlanjutan usaha penangkapan yang dilakukan oleh nelayan dengan adanya bantuan ini dinilai sangat baik. Pemanfaatan dana bantuan oleh nelayan dapat mengembangkan usahanya karena semakin meningkatnya pendapatan. Namun ada sebagian penerima program yang tidak berlanjut usahanya. Hal ini dapat dilihat dari banyaknya responden $(50 \%)$ yang menjawab bahwa penggunaan dana bukan untuk usaha perikanan dampaknya adalah usahanya tidak sebaik dengan penerima program yang memanfaatkan dana bantuan seluruhnya untuk usaha perikanan.

\section{KESIMPULAN DAN IMPLIKASI KEBIJAKAN}

\section{Kesimpulan}

Kinerja input, proses dan output PNPM-PB di 12 lokasi penelitian-secara administrasi sudah sesuai dengan pedoman teknis yang ditetapkan oleh pusat.

Permasalahan dan tantangan dalam pelaksanaannya program PUMP perikanan budi daya antara lain:

Kinerja input; adanya Pokdakan aspirasi yang tidak terdaftar di Dinas KP setempat menghambat proses verifikasi, Pokdakan masih banyak yang belum memahami proses pengusulan dan pembuatan proposal BLM karena kurangnya pengetahuan Pokdakan tentang pedoman teknis PUMP.

Kinerja proses; terbatasnya pendampingan dari fasilitator, kurangnya tenaga pendamping dalam melakukan pendampingan dan bimbingan di lapangan, selain keterbatasan pengetahuan dan keterampilan juga insentif dan sarana prasarana serta biaya operasional yang kurang memadai termasuk jangkauan wilayah yang terlalu luas.

Kinerja ouput; fungsi kelembagaan/ organisasi kelompok Pokdakan tidak berjalan, masing-masing anggota kelompok berjalan sendirisendiri. Pokdakan belum mampu mengembangkan kelompok menjadi kelembagaan keuangan mikro yang mandiri

\section{Implikasi Kebijakan}

Berdasarkan kinerja input, proses, output dan outcome, langkah strategi kebijakan prioritas yang perlu dilakukan adalah :

- Penentuan kriteria Pokdakan calon penerima program bukan untuk pemula, tetapi pembudidaya yang sudah melakukan usaha budi daya namun skala usahanya masih skala mikro dan menggunakan teknologi sederhana.

- Menempatkan minimal 2 (dua) orang tenaga pendamping (PPTK) untuk PUMP PB dan dikontrak minimal 3 (tiga) tahun (selama program PUMP PB dianggarkan), dan tidak berpindah-pindah dari program satu ke program lainnya sehingga pendampingan maupun monitoring, evaluasi dan pelaporan lebih terfokus dan berkelanjutan (tidak hanya pada tahun berjalan).

- Mekanisme pelaporan tidak hanya pada realisasi anggaran, tetapi lebih ditekankan lagi pada pelaporan pemanfaatan dan perkembangan usaha Pokdakan, tidak hanya pada tahun berjalan, tetapi minimal 2 (dua) tahun ke depan sehingga dapat terlihat perkembangan usaha Pokdakan apakah memberikan dampak yang signifikan terhadap indikator outcome.

\section{UCAPAN TERIMA KASIH}

Penulis mengucapkan terimakasih kepada Pusat Penelitian Sosial Ekonomi Kelautan dan Perikanan (PPSEKP) yang telah memfasilitasi pelaksanaan kegiatan penelitian ini, Ibu Siti Hajar 
sebagai penanggung Jawab Kegiatan Riset, dan rekan-rekan peneliti yang survey lapang dalam rangka pengumpulan data terkait dengan PUMP budidaya. Selain itu, ucapan terima kasih juga kepada segenap tim redaksi yang telah memberikan masukan dan arahan untuk penyempurnaan tulisan ini.

\section{DAFTAR PUSTAKA}

Direktorat Jenderal Perikanan Budidaya [DJPB]. 2011. Pedoman Teknis PUMP Perikanan Budi daya. Direktorat Jenderal Perikanan Budi daya. Jakarta.

Djalal, N. dan R. Lasabuda. 2012. Analisis Kinerja Stakeholder Program Nasional Pemberdayaan Masyarakat (PNPM)-Mandiri Kelautan Perikanan di Kota Ternate. Jurnal IImiah Platax. Vol. I-1, September 2012: 24-28.

Hikmayani, Y., R. H. Deswati dan Z. Nasution. 2013. Evaluasi Dan Strategi Peningkatan Keberhasilan Pelaksanaan Program Pengembangan Usaha Mina Pedesaan Perikanan Budi daya (Pump Pb): Pendekatan Analisis Prospektif. JurnalKebijakan Sosek KP Volume 3 No.1 2013; 47-65.

Idrus, M. 2009. Metode Penelitian Ilmu Sosial. Erlangga. Yogyakarta.

Kementerian Kelautan dan Perikanan [KKP]. 2009. Pedoman Pelaksanaan Program Nasional Pemberdayaan Masyarakat Mandiri Kelautan Dan Perikanan. Kementerian Kelautan dan Perikanan. Jakarta.

Karsidi, R. 2001. Paradigma Baru Penyuluhan Pembangunan dalam Pemberdayaan Masyarakat. Jurnal Mediator Volume 2 Nomor 1 2001: 115-125.

Mala, S. K. 2016. Peran dan Dinamika Kelompok Dalam Kehidupan Sosial Ekonomi Nelayan (Studi Kasus Di Desa Citemu Kecamatan Mundu Kabupaten Cirebon). Jurnal. Orasi, Volume 7 No. 1 Tahun 2016: 1-20.

Murdini, I. A. K, A. A. Putu Agung dan Ni GAG. E. Martiningsih. 2013. Pengaruh PNPM-MKP Terhadap Peningkatan Pendapatan Kelompok Tani Ikan Desa Pering Kecamatan Blahbatuh Kabupaten Gianyar. Jurnal Alam Lestari Volume 01 No. 02, April 2013: 112-221.

Nazir, M. 1999. Metode Penelitian, Ghalia Indonesia, Jakarta.
Soehartono, I. 2008. Metode penelitian sosial: Suatu teknik penelitian bidang kesejahteraan sosial dan ilmu sosial lainnya. Remaja Rosdakarya. Bandung.

Utomo, B. 2011. Program Nasional Pemberdayaan Masyarakat Pesisir Mandiri Kelautan dan Perikanan Kota Semarang Tahun 2010.http:// regional kompasiana.com/ 2011/06/20, diakses 30 Juli 2011. 